Cambridge Archaeological Journal

http://journals.cambridge.org/CAJ

Additional services for Cambridge Archaeological Journal:

CAMBRIDGE

Email alerts: $\underline{\text { Click here }}$

Subscriptions: $\underline{\text { Click here }}$

Commercial reprints: Click here

Terms of use : $\underline{\text { Click here }}$

\title{
Excavations at Bolsay Farm, a Mesolithic Settlement on Islay
}

Steven Mithen, Bill Finlayson, Nyree Finlay and Mark Lake

Cambridge Archaeological Journal / Volume 2 / Issue 02 / October 1992, pp 242 - 253

DOI: 10.1017/S0959774300000627, Published online: 22 December 2008

Link to this article: http://journals.cambridge.org/abstract S0959774300000627

How to cite this article:

Steven Mithen, Bill Finlayson, Nyree Finlay and Mark Lake (1992). Excavations at Bolsay Farm, a Mesolithic Settlement on Islay. Cambridge Archaeological Journal, 2, pp 242-253 doi:10.1017/S0959774300000627

Request Permissions : $\underline{\text { Click here }}$ 


\section{Excavations at Bolsay Farm, a Mesolithic Settlement on Islay}

\author{
Steven Mithen, Bill Finlayson \\ Nyree Finlay \& Mark Lake
}

Bolsay Farm is a Mesolithic settlement on the Isle of Islay in Western Scotland. It is located at the foot of Benin Tart a'Mhill, $76 \mathrm{~m}$ OD and c. $3 \mathrm{~km}$ from the coast of Loch Indall in the Rhinns of Islay (NR 225573) (Fig. 1). The settlement was discovered in 1989 by the Southern Hebrides Mesolithic Project (SHMP) and has been the subject of two seasons of excavation. This brief report describes these excavations and our current interpretation of the site. We begin by providing a summary of the aims and work of the SHMP to place the work at Bolsay Farm into its academic context.
The Southern Hebrides Mesolithic Project (SHMP)

The Southern Hebrides Mesolithic Project was established in 1988 with the aim of making a regional study of Mesolithic settlement in the southern Hebrides the islands of Islay, Jura, Colonsay and Oronsay which form a small archipelago off the west coast of Scotland (Fig. 2). Previous work in this area, by Mellars on Oronsay (1987) and Mercer (1968-86) on Jura raised several issues concerning the early postglacial which can only be satisfactorily tackled by moving away from a site or island focus towards a regional perspective on Mesolithic settlement. Until 1988 Colonsay was unexplored for Mesolithic sites, although the character of early postglacial occupation on that island was clearly crucial to an interpretation of the Obanian settlement on Oronsay and its relationship to the sites with narrow blade assemblages on Jura.

The Obanian, with its characteristic limpet hammers, harpoons and mattocks, and the narrow blade

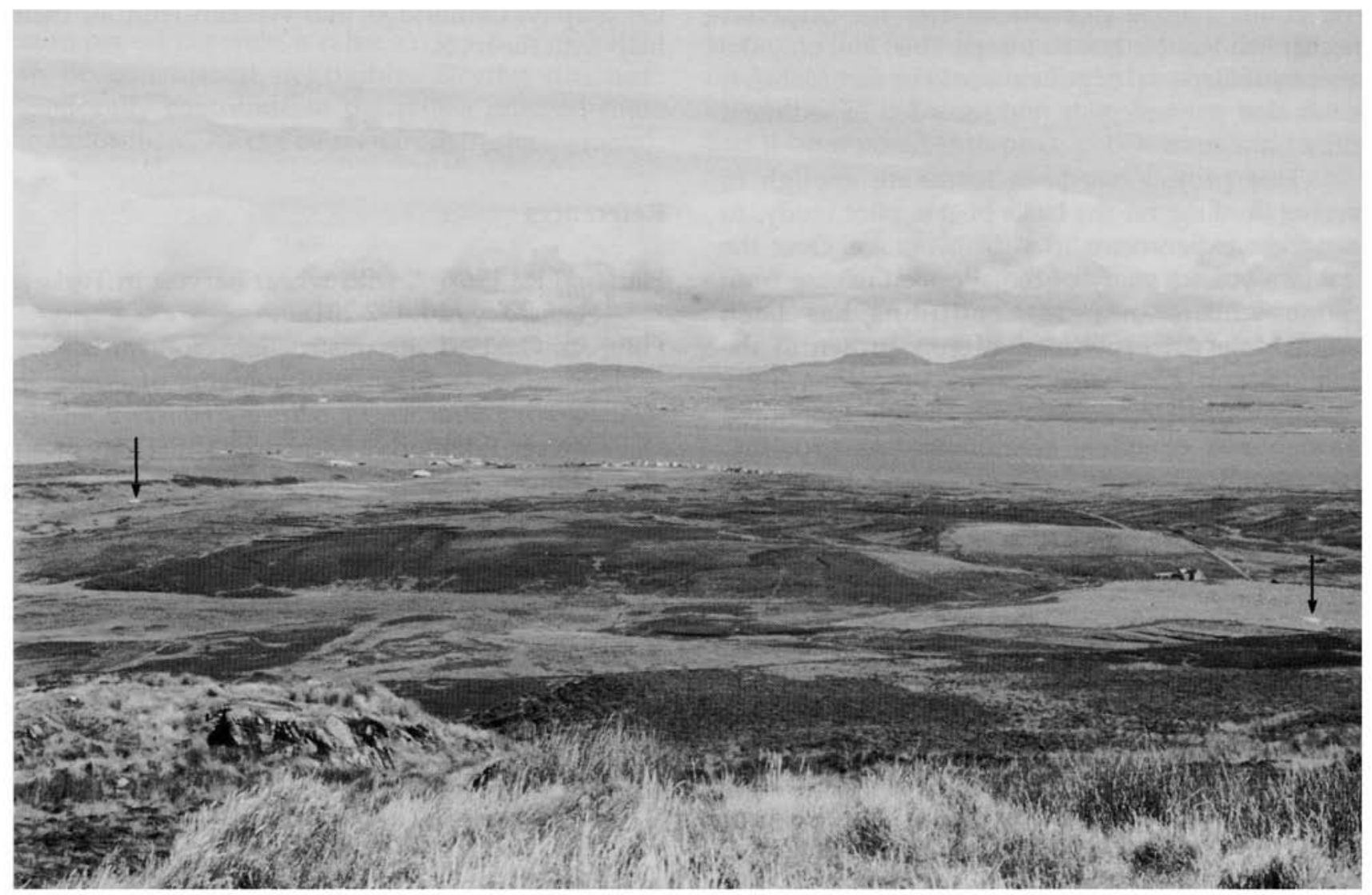

Figure 1. View from Benin Tart a'Mhill looking south across Loch Indall, Rhinns of Islay. Bolsay Farm is the area of pasture on the right hand side and the Mesolithic settlement is marked by the white speck of a polytunnel. At the far left a second polytunnel marks the location of Gleann Mor. 


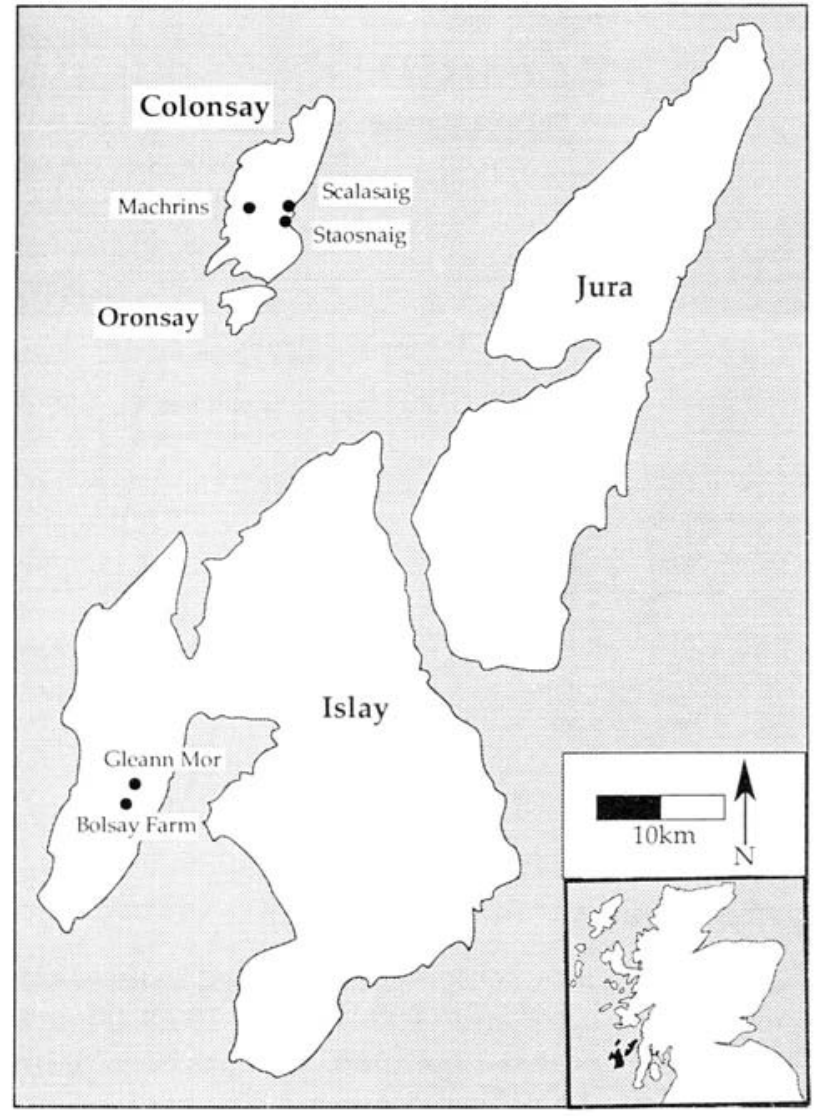

Figure 2. The southern Hebrides, showing location of Mesolithic sites studied by the project.

sites, with prismatic blade cores and high frequencies of microliths, provide the two cultural facies for the Scottish Mesolithic. Their relationship has been a matter of contention, with functional, cultural and chronological explanations offered in recent years (Woodman 1989). Resolution of this problem cannot be achieved until a more comprehensive data base for Mesolithic settlement is acquired. Further information concerning Mesolithic settlement on Islay, the largest and southernmost of the Hebrides, is particularly important. While a few microlithic scatters had been reported by 1988, and a new Mesolithic site at Newton recently excavated (McCullough 1988-9), the character of Mesolithic settlement on Islay was unknown.

The SHMP was established to undertake a programme of systematic survey and excavation on Colonsay and Islay to recover data pertinent to the Obanian/narrow blade issue. This data will also be important for addressing other issues. Notable among these is the process of colonization after the last glacial and the transition to agricultural economies in Western Scotland. Both are important for our understanding of British prehistory, but are currently discussed with a very limited data base of well dated and analyzed prehistoric settlements.

The central fieldwork goal of the project is the acquisition of a series of lithic assemblages, excavated and analysed in precisely the same manner, together with contextual information concerning site size, dating, features and spatial patterning. The explanation of the variability between such assemblages, in terms of preservation/excavation methods, site function and chronology will make a vital contribution to tackling the issues described above. In addition, programmes of non-excavation research are also necessary to understand inter-assemblage variability. In particular, studies of raw material availability in the southern Hebrides and experimental flint knapping are important and are currently being conducted by the SHMP. In the longer term, detailed geomorphological studies to understand sea level changes, pollen analysis to reconstruct past vegetation and re-analysis of the material from Mercer's sites are essential and will be conducted in a second phase of the SHMP starting in 1993.

\section{Field Work on Colonsay and the site of Staosnais} The SHMP has so far undertaken eight field seasons, four each on Colonsay and Islay. The work on Colonsay has involved survey by field walking and test-pitting. Microlithic assemblages, assumed to be Mesolithic on technological and typological grounds, have been recovered from three locations: Machrins, Scalasaig and Staosnaig (Mithen 1989; Mithen \& Finlayson 1991). It is only at the last of these locations that a substantial archaeological site with in situ remains has been found (Fig. 3). In general, the character of Mesolithic settlement on Colonsay appears to be rather ephemeral - in marked contrast to that on Islay.

Excavation at Staosnaig took place in September 1991 and March 1992 (Figs. 4 \& 5). The site is currently interpreted as a palimpsest of temporary camping sites created by Mesolithic foragers during short and infrequent visits to Colonsay. The 1990 excavation recovered a narrow blade assemblage and located a series of poorly preserved features cut into sand deposits on the prehistoric beach. Although the site is likely to be a palimpsest, flint densities are markedly lower than on the Islay sites described below. Thermoluminesence (TL) dates on burnt flint provide a mean date of $7.76 \pm 0.69 \mathrm{Ka}$ BP. In March 1992 a large feature, c. $4 \mathrm{~m}$ in diameter was discovered containing large quantities of burnt hazel nuts 


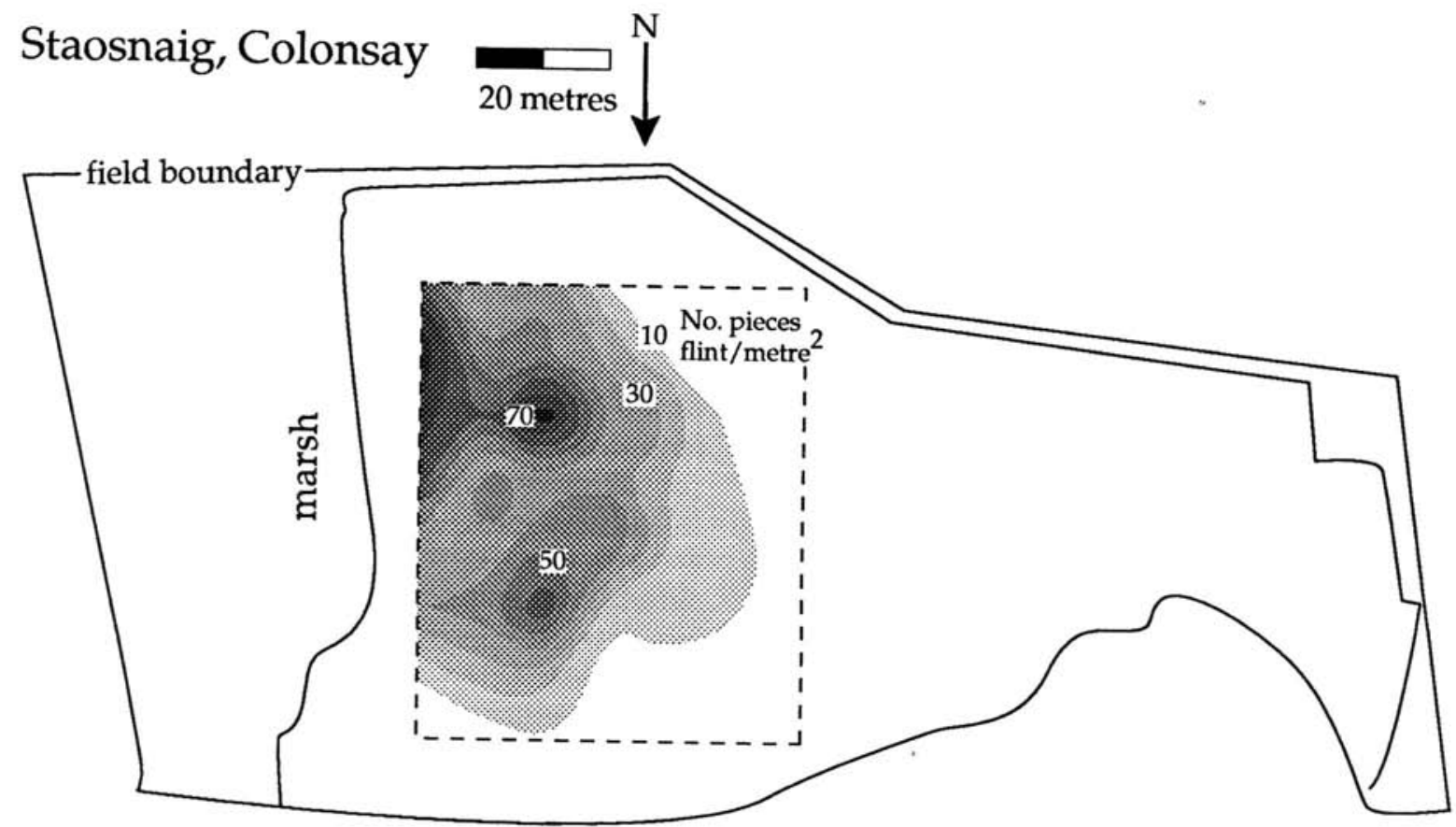

Figure 3. Flint distribution at Staosnaig, Colonsay, as determined by test-pitting in 1989.

and lithic artefacts, including limpet hammers and ground stone tools. This may be the remains of a heavily degraded shell midden. Consequently, Staosnaig provides a rare discovery of an association between Obanian limpet hammers and narrow blade technology. Whether these were contemporary technologies remains to be seen from the awaited radiocarbon dates. A large scale excavation at Staosnaig is planned for the summer of 1993.

\section{Gleann Mor, Islay}

The work on Islay has focussed on two sites - Gleann Mor and Bolsay Farm - both in the Rhinns peninsula in the north-west of Islay. Gleann Mor is a small,

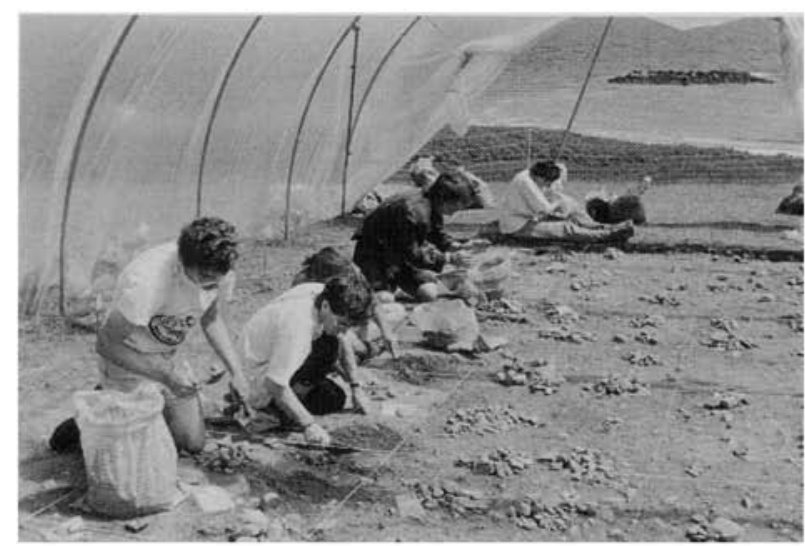

Figure 4. Excavation of the northern artefact scatter, Staosnaig, September 1991. discrete Mesolithic settlement excavated in three seasons between 1988 and 1990 (Mithen 1990) (Figs. 68). The site is located adjacent to, and has been partly destroyed by, an old sand quarry. The excavations, involving the plotting of thousands of artefacts, produced a large lithic assemblage (c. 23,000 pieces) and the site is thought to be a specialized hunting camp. The site has a radiocarbon date of $7100 \pm 125 \mathrm{BP}$ and a mean TL date on burnt flint of $8.11 \pm 0.98 \mathrm{Ka} B P$. It is an important settlement since there appears to have been a single occupation event. Almost all other Mesolithic sites in Scotland are complex palimpsests of numerous occupation events. As with the lithic material from Colonsay, a programme of post-exca-

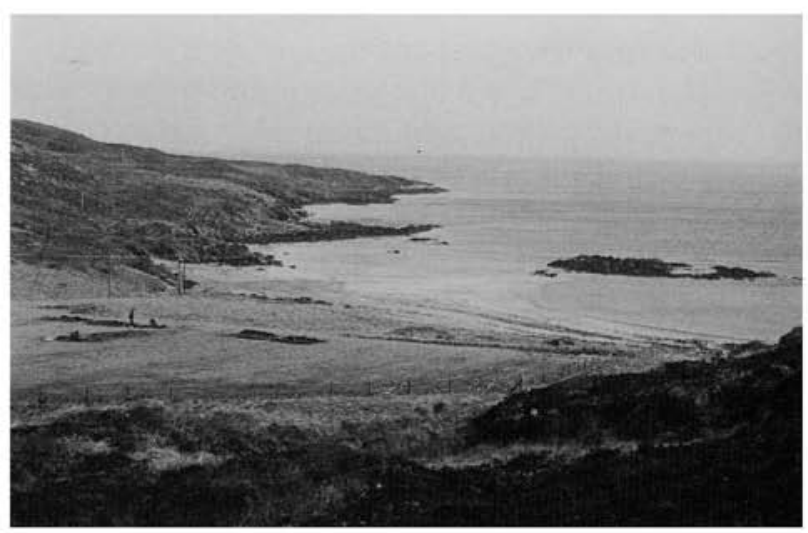

Figure 5. Excavations at Staosnaig, March 1992. 
Figure 6. Flint distribution at Gleann Mor sand quarry site, Islay, as determined by test-pitting in 1988.

\section{Gleann Mor, sand quarry site

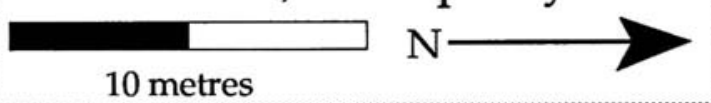

No. pieces 2 ; 100 ;
flint/metre

5000
7000
7000

900

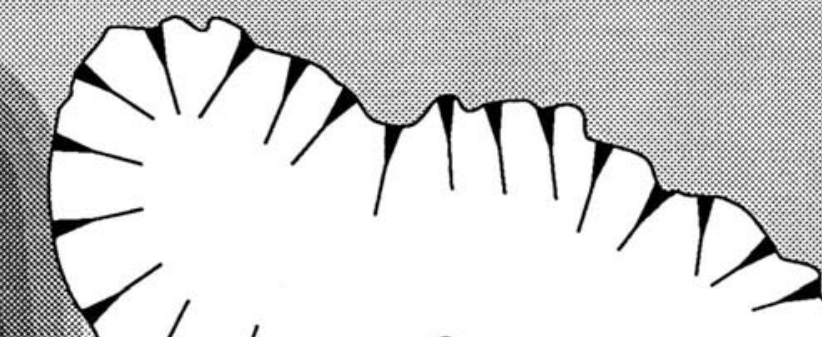

1100

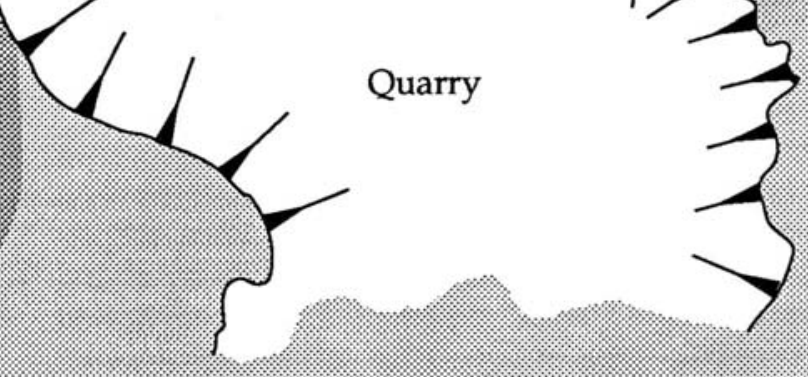

vation analysis is underway at present including technological/typological studies, microwear and spatial analysis.

Discovery of the Bolsay Farm site, 1989

During the 1989 SHMP field season on Islay the area of pasture at Bolsay Farm, c. $2 \mathrm{~km}$ west of Gleann Mor was investigated by test-pitting (Fig. 9). Lithic material had previously been recovered from these fields when they had been under plough (Wickham-

Jones, pers comm). The local farmer, Mr Clark of Craigfad, had made a small collection of artefacts, some of which were very similar to those recovered from Gleann Mor.

Over most of the field the test pits produced a low density background lithic scatter of between 560 pieces/metre square. While there was a suprisingly large number of retouched pieces in the assemblage, there was nothing diagnostic of the Mesolithic period. This material was heavily dominated by a brown/

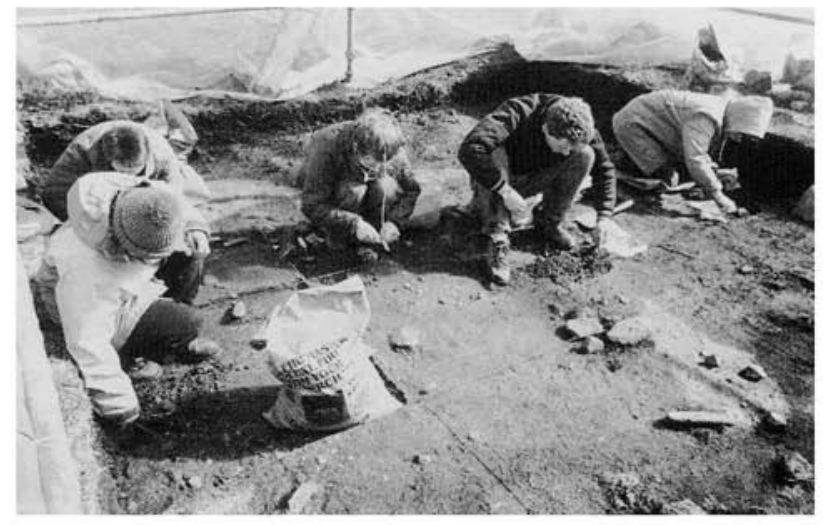

Figure 7. Excavations at Gleann Mor, Islay, August 1990 .

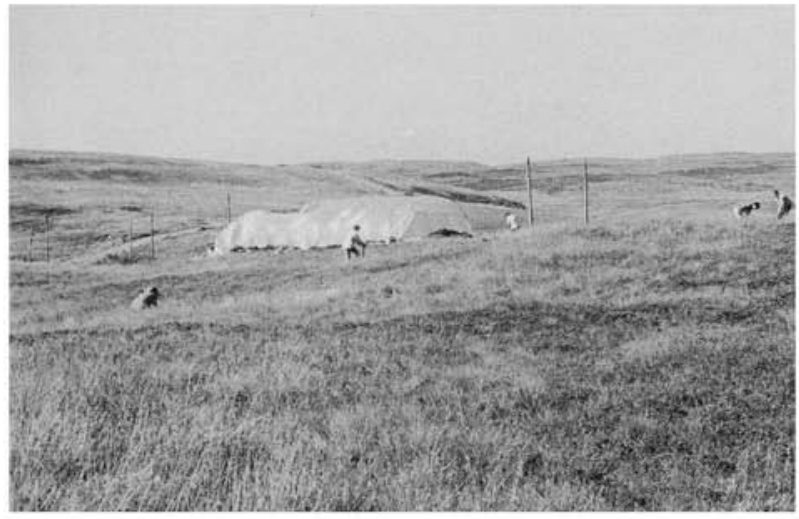

Figure 8. Excavation at Gleann Mor, April 1989. 


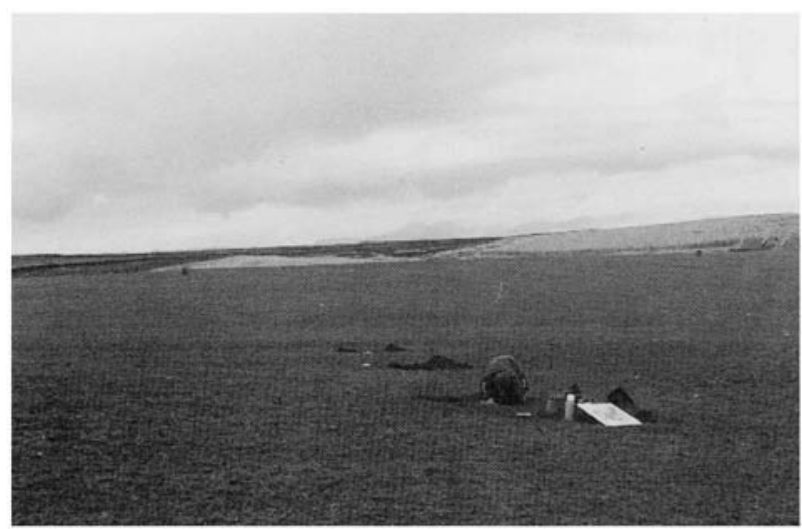

Figure 9. Test-pitting at Bolsay Farm, April 1989.

honey coloured flint, whereas on local Mesolithic sites it is usual to have a wider range of flint colours with a dominance of grey. The soil profile in these test pits consisted of $c .20 \mathrm{~cm}$ of plough soil directly overlying brown/orange glacial sediment. In the northwest portion of the field, however, this pattern was dramatically changed when one single test pit produced over 500 pieces of worked flint including numerous blade cores and microliths - an assemblage similar to that which we were currently excavating at Gleann Mor. Moreover, the soil profile changed to include a deep deposit $(c .1 \mathrm{~m})$ of varying sediments with a stratigraphy too complex to understand in a $0.5 \mathrm{~m}$ test pit.

The immediate area around this test pit was explored by test pits at 10 and $5 \mathrm{~m}$ intervals. These demonstrated a discrete, high density scatter of microlithic material in the north-west part of the field (Fig. 10) with technological and typological characteristics very similar to those in the assemblage from Gleann Mor.

\section{Excavations at Bolsay Farm}

Two seasons of excavation have taken place at Bolsay Farm. In 1990 a $7 \times 4 \mathrm{~m}$ trench was excavated in the eastern half of the microlithic scatter. The specific aim was to establish the stratigraphy of the site, with particular regard to the preservation of undisturbed Mesolithic deposits, and to acquire material for absolute dating. Owing to the unexpectedly large quantities of lithic material discovered, only a $0.5 \mathrm{x}$

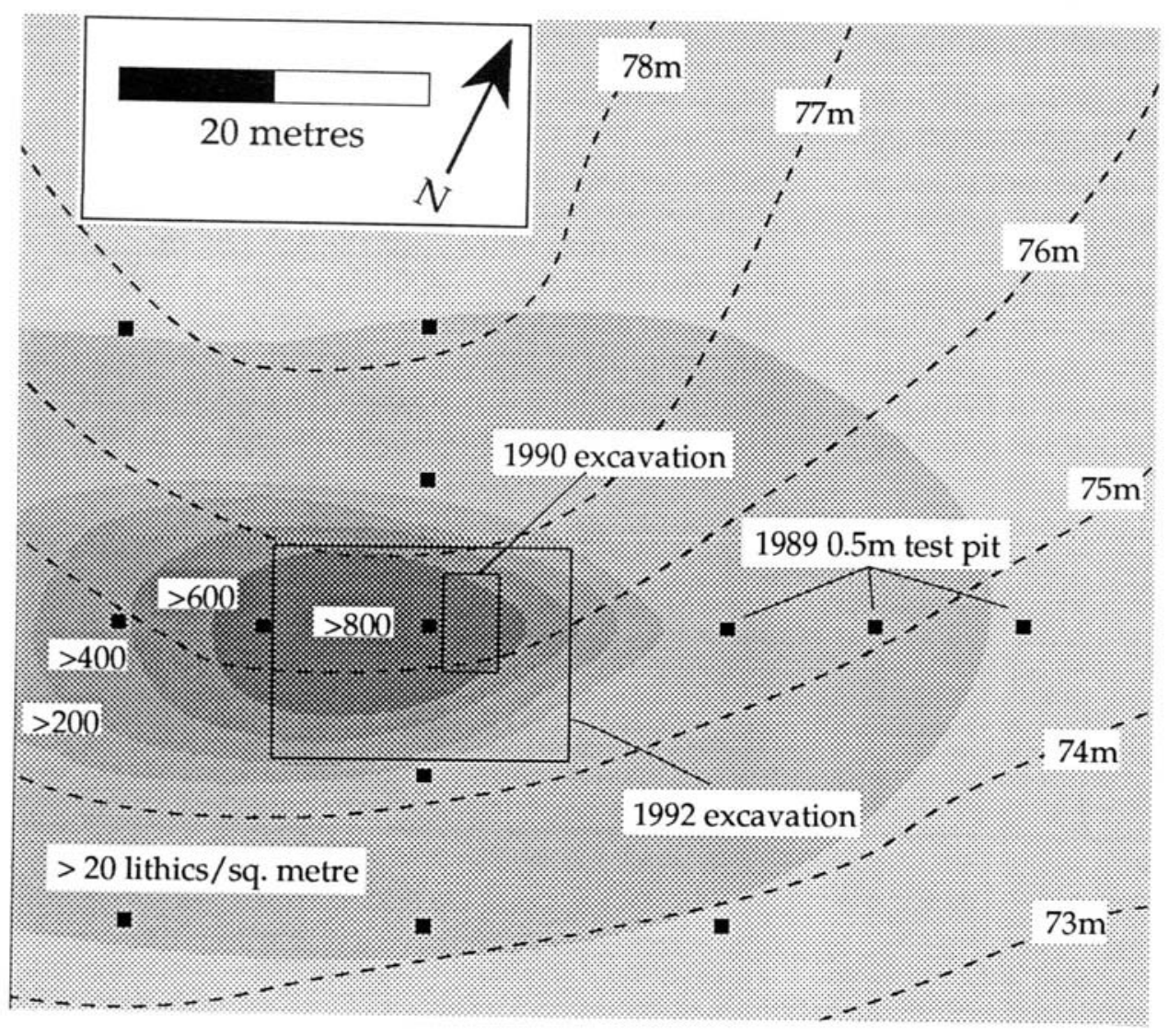

Figure 10. Flint distribution at Bolsay Farm as determined by test-pitting in 1989, and location of $1990 \& 1992$ trenches. 
Excavations at Bolsay Farm

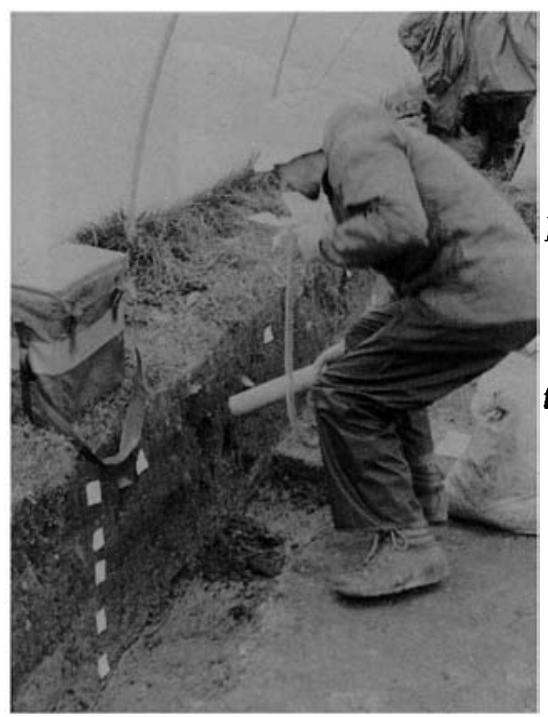

Figure 11.

Stratigraphic section exposed at

Bolsay Farm, August 1990. Dr N.Debenham of the British Museum is seen taking readings for thermoluminesence dating.

$7.0 \mathrm{~m}$ section of this trench was excavated through all contexts to the natural (Figs. $11 \& 13$ ).

This excavation demonstrated that an extensive area of Mesolithic occupation deposits was preserved at Bolsay Farm and consequently the 1992 excava- tion aimed to acquire data for a spatial study of artefact distributions. To this end, a $20 \times 15 \mathrm{~m}$ trench was opened (Fig. 12). Following removal of the topsoil and immediately underlying colluvial deposits by mechanical excavator, a $5 \mathrm{~cm}$ thick layer of Mesolithic occupation deposits (contexts 4 \& 5, see below) was removed over the complete area in $48000.25 \mathrm{~cm}$ quadrats. As with soil from the 1990 excavation, that from each quadrat was washed through a $3 \mathrm{~mm}$ sieve and finds 'picked' from the residue. During excavation, samples were regularly taken for flotation and environmental analysis. Evidence was found during the excavation of later prehistoric activity on the site in the form of pottery and a ground stone axe.

\section{Stratigraphy and site formation (Figs. 13 \& 14)}

At the base of the sequence at Bolsay Farm is a glacial marine sediment. This is principally an orange clay but varies in character across the 1992 trench from an orange gravel at the northern end to a yellow/white coarse sand in the south. A series of deposits are sandwiched between this and the overlying topsoil.

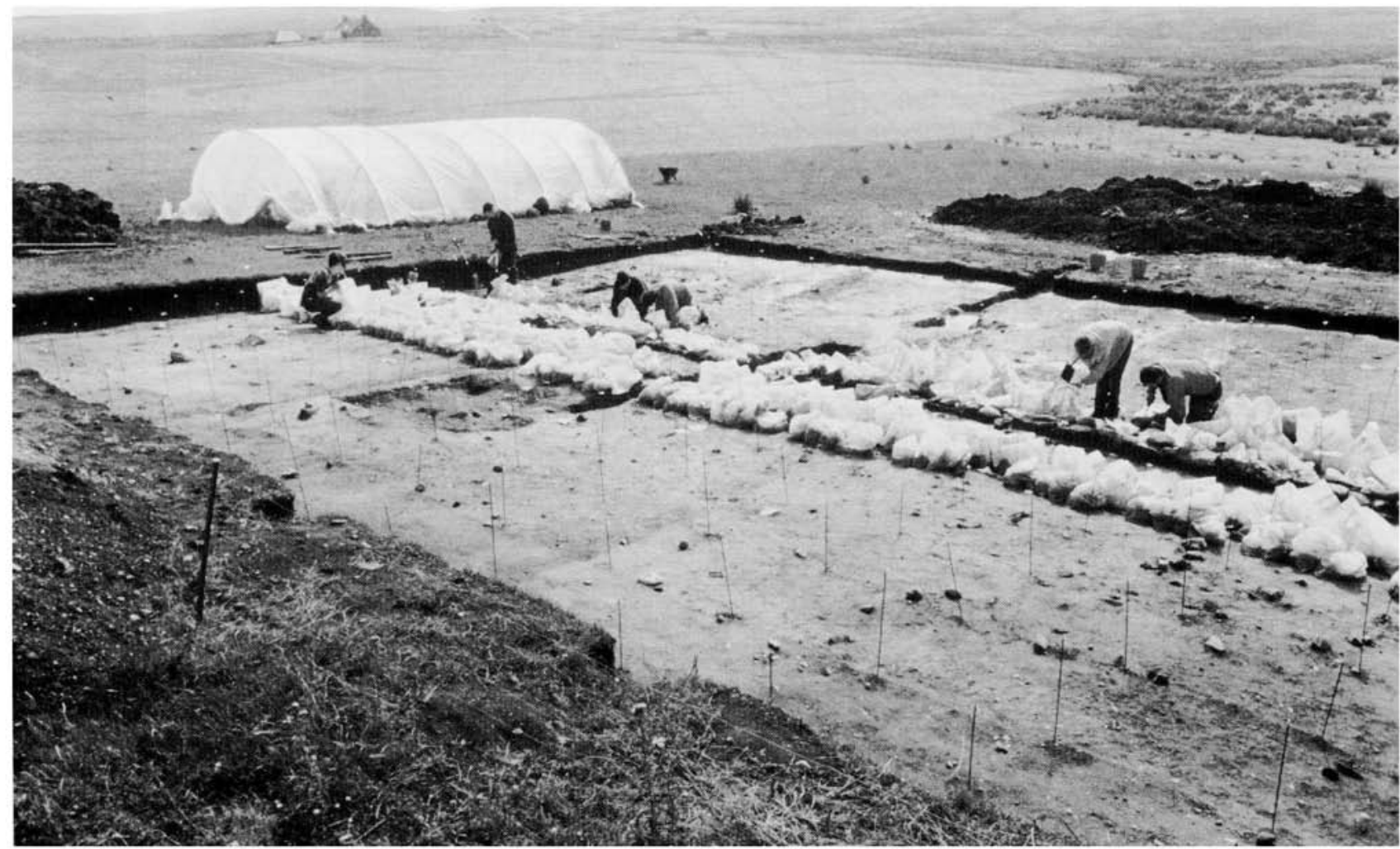

Figure 12. Excavation at Bolsay Farm, July 1992. The polythene sacks across the site contain soil from $0.25 \mathrm{~m}$ quadrats and are being labelled for wet sieving. 


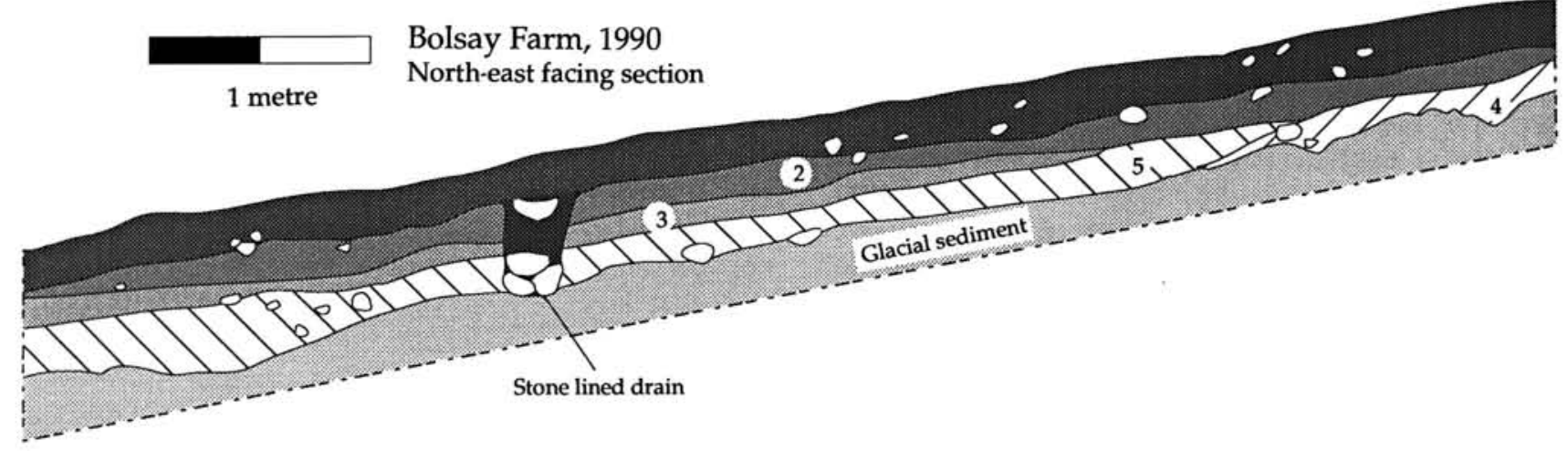

Figure 13. North-east facing section, Bolsay Farm 1990.

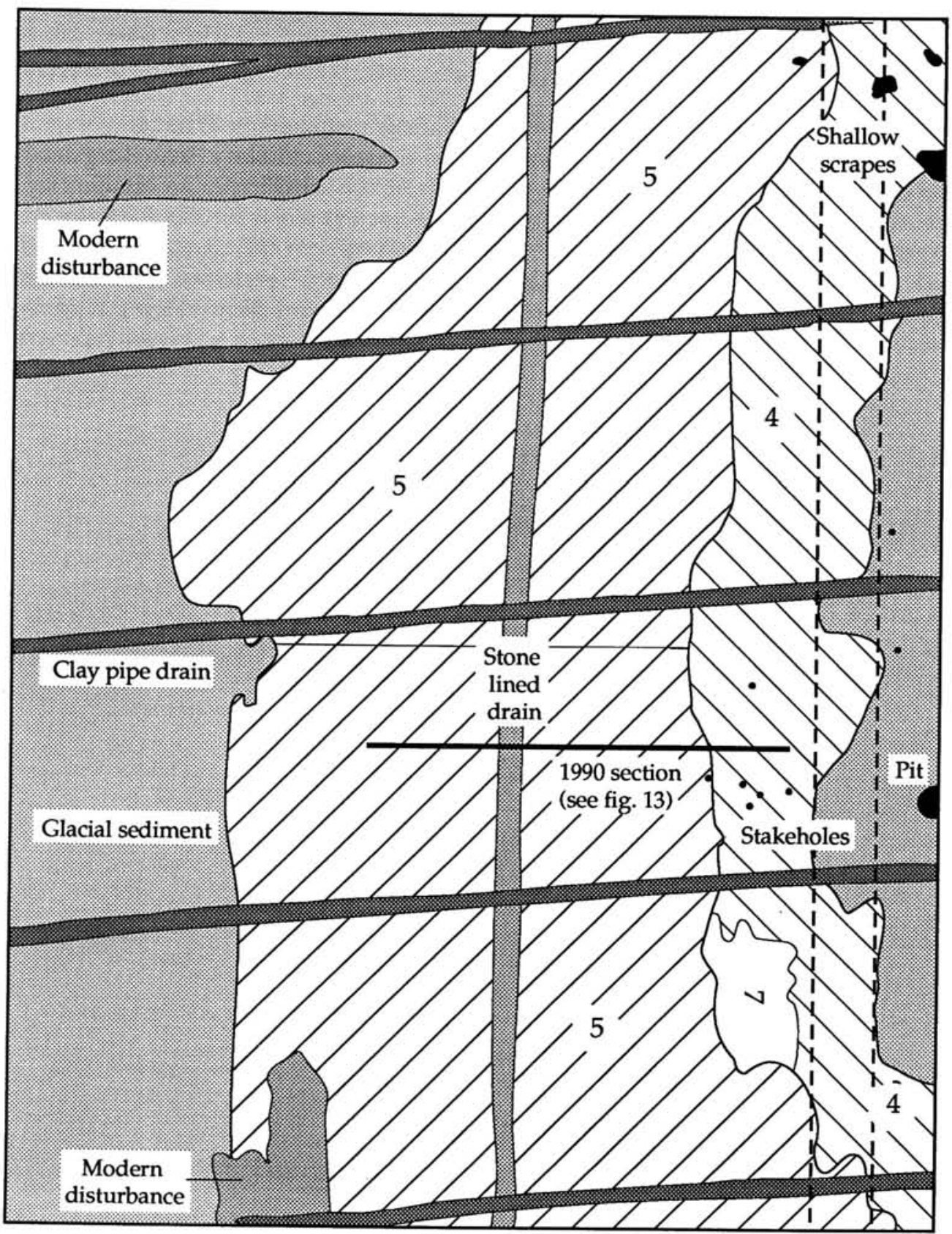

Figure 14. 1992

excavation plan, Bolsay Farm, showing the major contexts exposed following removal of ploughsoil and contexts 2 \& 3. The two dashed lines mark the $1 \mathrm{~m}$ strip for which debitage densities are illustrated in Fig. 15.

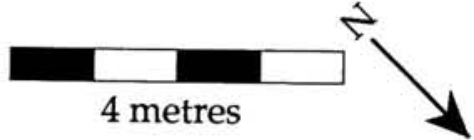


Directly above the glacial sediment is a grey podsol (context 5) or, at the northern end of the trench, a more compact pinky horizon with a higher clay and less organic content (4) which lenses out between the podsol and the glacial sediment. A series of poorly preserved features were found cut into this context. These two deposits ran east-west across the site filling a linear depression which is partly natural and partly from an artificial cut. Plough marks were found cut into the surface of context 5 . Between contexts 4 and 5 (interpreted as Mesolithic occupation deposits) and the topsoil was c. $40 \mathrm{~cm}$ of more (3) or less (2) compact brown soil, in which there were further plough marks. In the south-east part of the trench a thin lens of peaty sediment was sandwiched between contexts 5 and 3. A stone-built landdrain running east west had been cut into the deposits prior to the modern topsoil. Further clay pipe drains running approximately northsouth had been laid cutting through the topsoil. All the deposits between the glacial sediment and the topsoil have similar fractions of silt, sand and clay and contain large quantities of flint artefacts.

The current interpretation of this soil profile and process of site formation can be summarized in six phases of cultural and natural activity at the site. This sequence remains a working

Figure 15. Distribution of debitage (unretouched flakes and blades) and cores in a $20 \mathrm{~m} \times 1 \mathrm{~m}$ strip of the 1992 excavation trench. hypothesis, to be evaluated by the results of postexcavation studies.

1. Mesolithic occupation occured at the site $c .8000$ $\mathrm{BP}$ (see below for dating evidence). At this time, this area would have been heavily wooded and the soil a brown earth. Large quantities of knapping debris and stone tools were discarded. Features were cut into the brown earth and the underlying glacial sediment. Part of the site was located in a shallow depression just below the crest of the gentle rise in the Bolsay Farm fields. Occupation must have been extensive to have created such a large lithic assemblage. Contexts 4 and 5 are currently interpreted as the remains of the occupation surface. The first of these appears undisturbed with Mesolithic artefacts remaining in situ, while those in context 5 may have been disturbed by soil movement.

2. Following abandonment of the site, peat formation and podsolization of the soils took place. Peat formation is likely to have occurred by $c$. $6000 \mathrm{BP}$. The brown earth would have been transformed into a gleyed podsol overlying an iron pan. It is likely that the thin lens of peat (context 34 ) found above this layer is a remnant of the original peat cover.

3. Later prehistoric activity occurred in the area of Bolsay Farm. The character and date of this activity, and nature of the landscape and soils at this time, are currently unclear.

4. During the height of agricultural improvements on Islay during the late 19th/early 20th century drainage of the fields was undertaken. This probably involved deep ploughing to break up the iron pan and is the cause of the plough marks in the surface of context 5 .

5. As frequently happens following deep ploughing in highland locations, soil erosion occurred destroying part of the site. The settlement area within the shallow linear depression survived intact, although the surface may have been truncated. Eroding occupation deposits from immediately uphill accumulated onto the in situ deposits in the depression. This colluvial soil now forms contexts $2 \& 3$. In essence the upper part of the site slumped down to lie on top of the lower part. Following this, the stone drain was constructed by cutting into the colluvium. This drain initially appeared rather odd as it follows, rather than cuts across, the contours of the hill. It now appears to have been constructed specifically to cope with waterlogging caused 
by the depression containing Mesolithic deposits as it runs directly through the centre of these. Mr Clark, the local farmer, suggested that it dates to the 1920s on the basis of the herringbone arrangement of stones in its base.

6. Finally there occurred a phase of soil formation during which the modern plough soil was formed. This was followed by a further phase of drainage and current agricultural activity causing plough marks on the surfaces of the colluvial soil and of the in situ deposits in the northern part of the trench.

\section{The artefact assemblages}

The finds are dominated by flint artefacts (e.g. Fig. 16). The 1990 excavation produced 66,211 pieces of worked stone. Flint beach pebbles dominated the raw material with only minimal representation of other materials such as quartz, chalcedony and pitchstone. The likely source of flint is the west (Atlantic) coast of the Rhinns since the SHMP raw material survey has shown this to be particularly rich in flint beach pebbles. The majority of the flint artefacts excavated in 1992 remains within sieve residue waiting to be 'picked' during the 1993 post-excavation season. The artefacts from a $1 \mathrm{~m}$ wide strip across the site were fully recovered and catalogued during the excavation. These amount to over 25,000 pieces, including $c$. 800 microliths. As this constitutes approximately $8 \%$ of the area excavated in 1992 we suspect that the final assemblage from Bolsay Farm will amount to more than 500,000 pieces. This sample derives from probably no more than $10 \%$ of the original volume of occupation deposits. Consequently, the site is likely to have once had over 5 million pieces of worked stone.

Figure 15 shows the distribution of debitage (unretouched blades and flakes) and cores in this $1 \mathrm{~m}$ strip at the northern end of the trench. Considerable spatial variability can be seen and once the whole site has been processed in this manner a detailed spatial analysis of artefact distributions will be made. The following notes on the lithic assemblage are based on that excavated in 1990. It is currently unclear how representative this sample is of the site as a whole.

A breakdown of this assemblage into artefact classes is given in Figure 17. In general, the technology is similar to that found in other narrow blade assemblages and reflects on-site flint knapping and probably a wide range of activities. Among the microliths so far analyzed from the 1992 excavation have been two broad blade microliths, generally thought of as preceeding narrow blade technology and representing an earlier Mesolithic. The
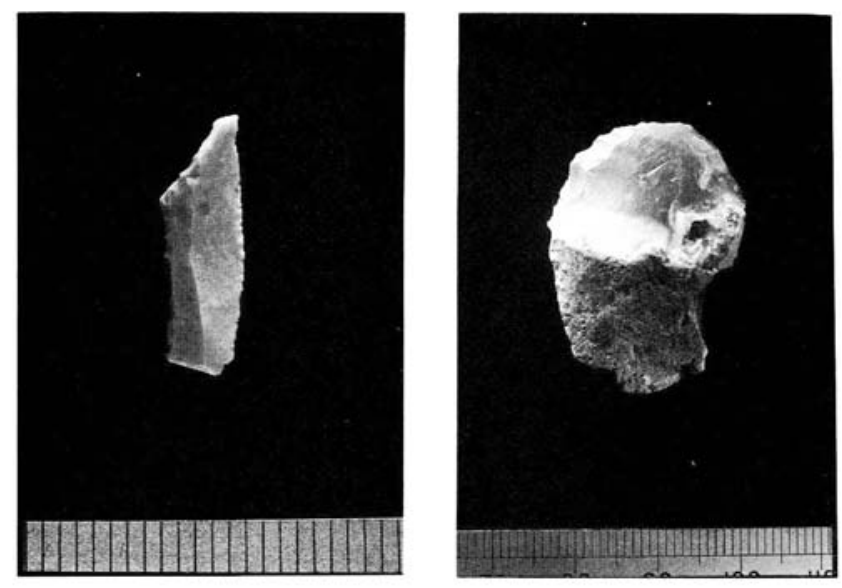

Figure 16. A scalene triangle and scraper from Bolsay Farm.

assemblage is particularly notable in the following respects:

1. Density. The lithic material is very densely distributed, reaching over 2000 pieces per square metre in certain areas. Moreover the high density area is extensive for a Mesolithic site in Scotland and suggests substantial occupation, or repeated re-occupation, of the site.

2. Contamination. Unlike the site of Kinloch on Rhum (Wickham-Jones 1989), there is no evidence of any later prehistoric flintwork at Bolsay. This is perhaps surprizing in the light of the pottery assemblage from the site and later prehistoric flintwork located elsewhere in the fields at Bolsay Farm.

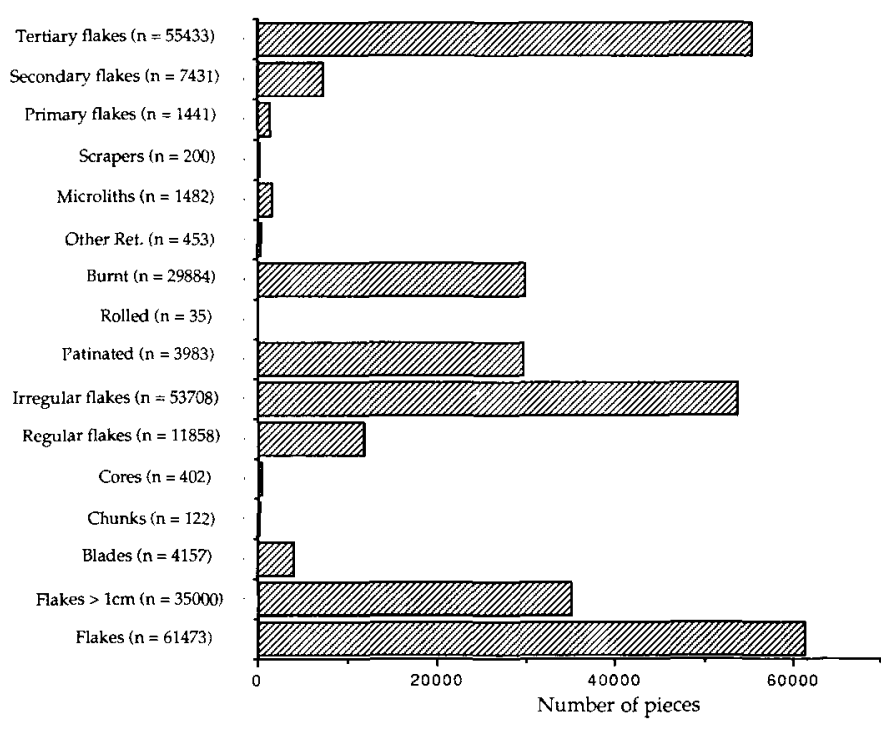

Figure 17. Bolsay Farm: 1990 assemblage composition $(n=$ 66,211 ). 
3. Flake/blade ratios. The assemblage has a ratio of blades to flakes similar to that at Gleann Mor, which is higher than that at Staosnaig and Kinloch but lower than Mount Sandel (using figures from the in situ deposits at that site: Woodman 1985) (Fig. 18a). The contrast with Staosnaig is likely to be a true reflection of knapping strategies since raw material characteristics remain constant. The contrast with Mount Sandel may derive from numerous factors including raw material availability, site function and classification methods.

4. Cores/retouched frequency. The similarity between the Bolsay and Mount Sandel assemblages is also seen in the relative proportions of cores and retouched pieces (Fig. 18b). Cores are generally at a low frequency, i.e. less than $1 \%$, while retouched pieces amount to more than $3 \%$ of the assemblage. This is markedly high for a Mesolithic site in Scotland.

5. Stratigraphic homogeneity. The assemblages from the plough soil, colluvial deposits ( $2 \& 3$ ) and the in situ horizons ( 4 \&) are similar with respect to the flake/blade ratios and the frequency of retouched pieces and cores. The variability present - a slight decrease in core frequency and increase in retouched frequency - can be accounted for by the use of only hand sorting for the plough soil and wet sieving for lower contexts. This assemblage homogeneity confirms the site formation scenario proposed above.

In addition to the flint artefacts there were two other main classes of finds from the 1992 excavation - nonflint stone artefacts and pottery. The stone artefacts are principally elongated pebble tools (EPTs), similar to those recovered in 1992 from Staosnaig. These are of varying size and shape with bevelled or abraded ends. Attempts are being made to collect phytoliths from the surface of these tools. These are yet to be studied, but it is possible that some of the tools may be limpet hammers. In addition, there were numerous sherds of prehistoric pottery from the surface of contexts 4 and 5 . These are currently being analyzed and are likely to be Late Neolithic/Early Bronze Age in date. Other finds include a broken ground stone axe that had been re-used as a flake core.

\section{Features}

In the light of the quantity of lithic artefacts and area of occupation deposits at Bolsay Farm, the quantity and quality of features have been disappointingly low. This may be the result of truncation of the occupation deposits by erosion and ploughing, rather than a reflection of the original character of the site. The 1990 excavation revealed five stake holes cut through context 4 at the northern end of the trench (Fig. 19). Three of these formed a line at $c .20 \mathrm{~cm}$ intervals and were vertical. The two others were inclined at $c .60$ degrees. At the southern end of the trench a pit was discovered and small quantities of tree bark and charcoal recovered from the fill. This was both sealed by and cut into context 5 . When the excavation of this pit was completed in 1992, it was found to have a dumbell shape, $2.4 \mathrm{~m}$ long and $1.2 \mathrm{~m}$ wide, with a highly irregular base comprising a
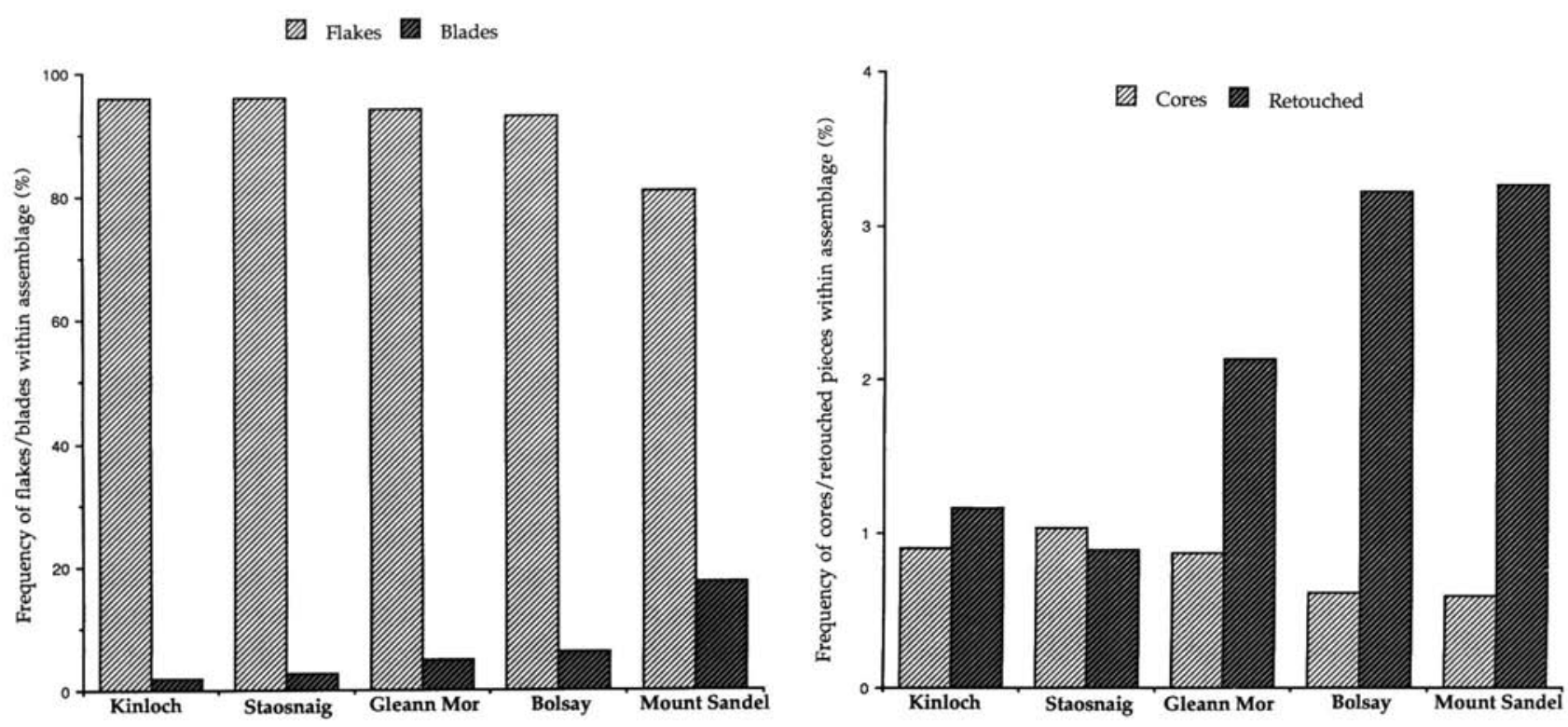

Figure 18. Inter-assemblage comparisons of a) flake/blade ratios and b) frequencies of cores and retouched artefacts. 


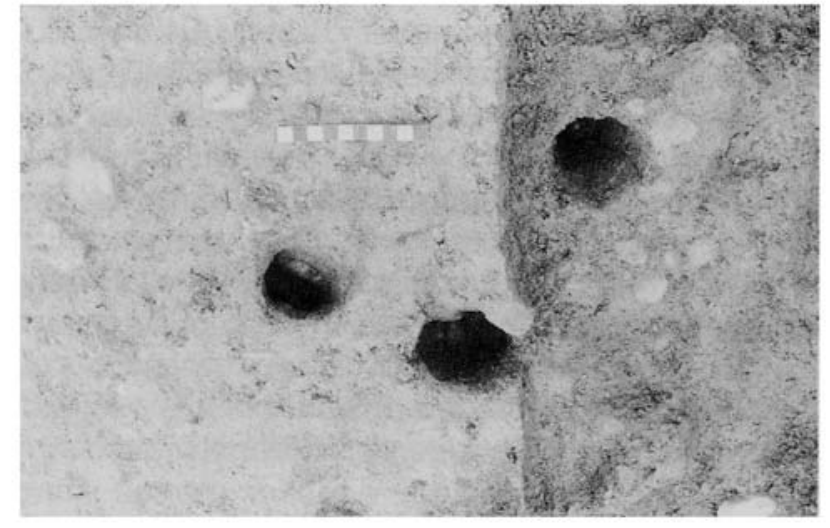

Figure 19. Stakeholes cutting context 4, Bolsay Farm 1990.

complex arrangement of concave cavities.

A further ten features were discovered and excavated during the 1992 season. These were located in the northern half of the excavation and were either cut into the glacial sediment or context 4 (one is cut into context 5). Two of these were small stakeholes of less than $70 \mathrm{~mm}$ in diameter and depth. No spatial patterning is evident when these are viewed in conjunction with the stakeholes excavated in 1990. The northern edge of the excavation truncated a circular pit $0.6 \mathrm{~m}$ in diameter and $0.35 \mathrm{~m}$ deep. This feature was cut into the glacial sediment and filled with an uncompacted pink/brown sandy clay containing small charcoal flecks. The fill was separated from the overlying layer (context 2) by an incipient iron-pan. Excavation of a trench through context 4 revealed that this layer is truncated to the south west by an artificial cut $c .3 \mathrm{~m}$ wide and at least $7 \mathrm{~m}$ long. The north side of the cut extended into the sterile subsoil resulting in a narrow horizontal terrace on an otherwise sloping surface. Whether this is a house platform or other large structure must remain speculative. This cut is filled by context 5 which also lenses out over the living surface to the north and the sterile subsoil to the south

The remaining six features were shallow scrapes of less than $0.75 \mathrm{~m}$ maximum dimension. Most of these were irregular in shape but with roughly straight sides and a flat base. They were filled with soil indistinguishable from, or derived from, context 4. This is suggestive of features left open and filled by trampling, silting or deliberate levelling. Hence they are probably the result of ephemeral or opportunistic activity rather than, for example, systematic disposal of rubbish - even the 1990 pit which preserved a thin lens of bark contained very little organic material.
Absolute dating.

A radiocarbon date of $7250 \pm 145 \mathrm{BP}$ from charcoal found in the pit was obtained by Dr Roy Switsur in Cambridge. Dr Nick Debenham from the British Museum has conducted TL dating on burnt flints and sediments from the site. The mean TL date on burnt flint from context 2 is $8.33 \pm 0.85 \mathrm{Ka} \mathrm{BP}$, and from context $5,7.71 \pm 0.64 \mathrm{Ka} \mathrm{BP}$. These are not significantly different and give a mean TL date for the settlement of $7.93 \mathrm{Ka} \mathrm{BP}$.

\section{Summary}

The final interpretation of Bolsay Farm must await a series of post-excavation studies including cataloguing of the large lithic assemblage, detailed technological studies on samples of cores and retouched artefacts, spatial analyses and microwear studies. Comparisons will need to be made with the assemblages from Staosnaig and Gleann Mor - and hopefully with further sites to be discovered and excavated during phase II of the SHMP. Interpretation of these assemblages will also draw upon the results of experimental flint-knapping and raw material survey. Moreover, micromorphological analysis of the Bolsay sediments and other environmental studies may serve to refine, or possibly change, our current understanding of site formation and enable us to place this site in its palaeoecological context.

At present, we can simply note that the Mesolithic settlement at Bolsay Farm is remarkable for the quantities of lithic debitage and retouched tools, particularly microliths. The most likely interpretation is that these derive from many small occupation events creating a large palimpsest of discarded material. However, there may also have been one or a few large occupation events at Bolsay, perhaps taking the form of a base camp for hunters using satellite sites such as Gleann Mor and Staosnaig. The absence of large features may be indicative of many small occupations, although it is likely that this partly derives from truncation of the surviving deposits. Spatial analysis of artefact distributions may help to resolve the character of past occupation.

The reason for repeated occupation most likely lies with the local topography. The site is a few hundred metres from Loch a'Bhogaidh which would have been a large lake during the early postglacial. It lies on the south side of a small rise and would have been usually down-wind and out of sight of deer grazing in the area of Ben Tart a'Mhill (assuming that the prevailing winds were from the Atlantic). 
Indeed, Mr Ken Aldridge, a local gamekeeper and hunter, suggested that the site is situated perfectly for hunting of deer in the modern landscape. This is largely treeless, in contrast to the early postglacial, but if the movements of deer were controlled principally by topography this may provide an explanation for the obvious attractiveness of the Bolsay Farm settlement to Mesolithic hunter-gatherers.

\section{Steven Mithen \\ Department of Archaeology \\ University of Reading \\ Whiteknights \\ PO Box 217 \\ Reading \\ RG6 $2 A H$ \\ Bill Finlayson \\ Centre for Field Archaeology \\ University of Edinburgh \\ Nyree Finlay \\ 20 Mortonhall \\ Park Avenue \\ Edinburgh \\ Mark Lake \\ Department of Archaeology \\ University of Cambridge}

\section{Acknowledgements}

For financial support of the Southern Hebrides Mesolithic Project we would like to thank The British Academy, The McDonald Institute, The Society of Antiquaries of London, The Society of Antiquaries of Scotland, The Russell Trust and the Robert Kiln Trust. We also thank Historic Scotland for partly funding the 1992 excavation at Bolsay Farm. We are grateful to the British Museum and Nick Debenham for the thermoluminesence dates and to Roy Switsur, Cambridge for the radiocarbon dates. Advice concerning the interpretation of the soil profile at Bolsay was kindly given by Richard McPhail and Charlie French, and comments on the pottery by Ann MacSween. The excavations at Bolsay were made possible by kind permission of Mr Clark, Alan Clark and Alex Clark of Craigfad Farm. We thank Gilbert Marshall and David Thomas for assisting with site supervision at Bolsay. Of the many people who have given us help and advice on Islay since 1988 we would particularly like to thank Dr Malcolm Ogilvie, Mr Ken Aldridge and the Islay Museum of Island Life.

\section{References}

McCullough, R., 1989. Excavations at Newton, Islay. Glasgow Archaeological Journal 15, 21-53

Mellars, P., (ed) 1987. Excavations on Oronsay. Edinburgh: Edinburgh University Press

Mercer, J., 1968. Stone tools from a washing limit deposit of the highest post-glacial transgression, Lealt Bay, Isle of Jura. Proceedings of the Society of Antiquaries of Scotland 100, 1-46

Mercer, J., 1970. Flint tools from the present tidal zone, Lussa Bay, Isle of Jura. Proceedings of the Society of Antiquaries of Scotland 102, 1-30

Mercer, J., 1971. A regression time stone-workers' camp, 33ft OD, Lussa River, Isle of Jura. Proceedings of the Society of Antiquaries of Scotland $103,1-32$

Mercer, J., 1972. Microlithic and Bronze Age camps, 75-26 ft OD, N.Carn, Isle of Jura. Proceedings of the Society of Antiquaries of Scotland 104, 1-22

Mercer, J., 1974. Glenbatrick Waterhole, a microlithic site on the Isle of Jura. Proceedings of the Society of Antiquaries of Scotland 105, 9-32

Mercer, J. 1980. Lussa Wood I: the late-glacial and early post-glacial occupation of Jura. Proceedings of the Society of Antiquaries of Scotland 110, 1-32

Mercer, J. \& Searight, S., 1986. Glengarrisdale: confirmation of Jura's third phase. Proceedings of the Society of Antiquaries of Scotland 116, 41-55

Mithen, S., 1989. New evidence for Mesolithic settlement on Colonsay. Proceedings of the Society of Antiquaries of Scotland, 119, 33-41

Mithen, S. 1990. Gleann Mor: A Mesolithic site on Islay. Current Archaeology 119, 376-7

Mithen, S. \& B. Finlayson., 1991. Red deer hunters on Colonsay? The implications of Staosnaig for the interpretation of the Oronsay middens. Proceedings of the Prehistoric Society 57(2), 1-8

Wickham-Jones, C., 1990. Rhum: Mesolithic and later sites at Kinlock. Edinburgh: Society of Antiquaries of Scotland Monograph Series, 7

Woodman, P.C., 1989. A review of the Scottish Mesolithic: a plea for normality! Proceedings of the Society of Antiquaries of Scotland 119, 1-32

Woodman, P.C., 1985. Excavations at Mount Sandel 1973-77. Belfast: HMSO, Northern Ireland Monographs, No. 2 